\title{
Aktywność posłów do Parlamentu Europejskiego IX kadencji na portalu społecznościowym Facebook - analiza porównawcza
}

\section{Activity of Members of the European Parliament of the $9^{\text {th }}$ term on the social platform Facebook - comparative analysis}

\section{Abstract}

Social media has changed the social lives of humans. The real-world activities are conducted more often on the Internet; the content posted on such social networking sites as Facebook may serve here as an example. Activity in social media is particularly important for politicians and public figures since such a means of communication allows them to maintain direct contact with voters and citizens. Social media also serves as a platform for creating an image and a personal brand of a politician. Due to the activity on these types of platforms, lesser known people can gain wider recognition and reach a larger group of recipients. However, it should be also noted that as far as public figures are concerned, increased activity does not always denote the achievement of a goal. Politics are simply unpredictable and there are many factors influencing voting preferences.

Keywords: Facebook, Social media, image, elections, Podkarpackie voivodeship 


\section{Активность депутатов Европарламента IX созыва в социальной сети Facebook - сравнительный анализ}

\section{Аннотачия}

Социальные медиа изменили социальную жизнь человека. Все чаще реальная деятельность переходит в Интернет, а контент, который размещается на порталах, таких как Facebook, является тому примером. Активность в социальных сетях особенно важна для политиков и общественных деятелей, которые благодаря таким формам общения могут поддерживать прямые контакты с избирателями и гражданами. Социальные сети также служат платформой для создания имиджа и личного бренда политика. Благодаря активности на таких платформах малоизвестные люди могут получить более широкое признание и охватить большую аудиторию. Однако следует помнить, что в случае общественных деятелей повышение активности не всегда означает достижение намеченной цели. Политика непредсказуема и электоральные предпочтения зависят от многих факторов.

Ключевые слова: Facebook, социальные сети, имидж, выборы, Прикарпатье

\section{Wprowadzenie}

Tednym ze sposobów komunikowania politycznego oraz kreowania wizerunku polityka jest aktywna działalność w Internecie, ze szczególnym uwzględnieniem mediów społecznościowych takich jak m.in. Facebook. Portal ten stał się na tyle popularny, że w dobie powszechnej ,,smartfonizacji” i ,internetyzacji” korzystają z niego nie tylko osoby prywatne, ale także osoby publiczne w tym również politycy. Aby być obecnym w świadomości coraz młodszego wyborcy, kampania rzeczywista wspomagana tradycyjnymi formami komunikacji w ostatnich latach została również uzupełniona aktywnością w Internecie - jest to tzw. kampania online. Chcąc wzbudzać zaufanie wyborców oraz być wiarygodnymi w opinii publicznej, politycy, którzy decydują się na działalność w sferze Internetu, powinni mieć świadomość, że ich konta, profile i/lub strony będą atrakcyjne dla odbiorcy wyłącznie wtedy, gdy zawierają aktualne informację dotyczące działalności danej osoby, ale także gdy są prowadzone systematycznie, a nie okazjonalnie na potrzeby danej kampanii wyborczej (Marszałek-Kawa, Plecka, 2018).

Komunikacja aktorów politycznych, z wykorzystaniem nowych mediów (w tym mediów społecznościowych), a także jej wpływ na zachowania wyborców (elektoratu) to nowy problem badawczy w polskiej politologii 
(Bodys, 2016, s. 165). Badania prowadzone w tym zakresie zaowocowały licznymi publikacjami dotyczącymi sposobów oraz zakresu wykorzystywania mediów społecznościowych przez aktorów politycznych (zob. m.in. Adamik-Szysiak, 2014a; 2014b; Bodys, 2015; 2016; Posyłek, 2017a; Szwed-Walczak, 2017). Tematem badań było również wykorzystanie serwisów społecznościowych w komunikowaniu politycznym na szczeblu lokalnym (zob. m.in. Bąk, Kubisz-Muła, 2017; Boratyn, 2018; Choroś, Skrabacz, 2014a; 2014b; Olszanecka-Marmola, 2015; Posyłek, 2017b). Można zatem zauważyć, że nowoczesna komunikacja polityczna z wykorzystaniem portalu Facebook, a także możliwości, z jakich dzięki jego właściwemu zastosowaniu mogą korzystać osoby aspirujące do pełnienia funkcji publicznych (politycy), $\mathrm{w}$ coraz większym stopniu interesuje rodzimych badaczy.

Wykorzystanie mediów społecznościowych (w tym portalu Facebook) do komunikacji politycznej i społecznej posiada również bogatą literaturę anglojęzyczną (zob. m.in. Andersen, Medaglia, 2009; Sveningsson, 2014; Fung, Russon Gilman, Shkabatur, 2013; Bossetta, Dutceac Segesten, Trenz, 2017).

Celem niniejszego artykułu jest porównanie aktywności posłów do Parlamentu Europejskiego IX kadencji, z okręgu nr $9^{1}$, na portalu społecznościowym Facebook w okresie trwania kampanii wyborczej z okresem powyborczym po ogłoszeniu wyników wyborów, a także odpowiedź na pytanie badawcze czy Elżbieta Łukacijewska, Tomasz Poręba i Bogdan Rzońca prowadzą aktywną i systematyczną komunikację z użytkownikami portalu Facebook. Dodatkowej analizie poddana zostanie aktywność przedwyborcza, celem zestawienia z wynikami wyborów. Dzięki temu możliwym będzie odpowiedzenie na pytanie badawcze czy kandydat, który publikuje więcej treści, w ostatecznym rozrachunku zdobywa więcej głosów wyborców. Dobór próby badawczej został określony celowo (dobór celowościowy). Badaniom poddano tych polityków z województwa podkarpackiego, którzy w ostatecznym rozrachunku uzyskali mandaty europosłów i dostali się do Parlamentu Europejskiego.

Badany okres przedwyborczy obejmował ostatnie trzy tygodnie kampanii wyborczej, tj. od dnia 6 maja do 24 maja 2019 roku i został porównany z okresem powyborczym, tj. od dnia 27 maja do 14 czerwca 2019 roku. Zarówno

${ }^{1}$ Okręg wyborczy nr 9, obejmujący obszar województwa podkarpackiego - jeden z 13 okręgów wyborczych właściwych dla Polski. 
w pierwszym, jak i w drugim okresie porównane zostały wszystkie wpisy (posty) zamieszczone na stronach europosłów - zdjęcia, materiały wideo, plakaty, ulotki, relacje itp., a także wszystkie reakcje pozostawione przez pozostałych użytkowników portalu Facebook - komentarze, dyskusje, udostępnienia.

Na potrzeby artykułu postawiono następujące hipotezy badawcze: 1) aktywność eurodeputowanych wybranych do Parlamentu Europejskiego IX kadencji z okręgu nr 9 była znacząco wyższa przed wyborami aniżeli po wyborach, 2) wzmożona aktywność na portalu Facebook nie przekłada się na korzystniejszy wynik wyborczy, 3) celem aktywności kandydatów było kreowanie wizerunku w taki sposób, aby przyciągnąć potencjalnego wyborcę.

W artykule skorzystano z dwóch metod badawczych: metody porównawczej oraz analizy przypadków. Dzięki zastosowaniu metody porównawczej możliwym było zaprezentowanie aktywności wszystkich europosłów IX kadencji, wybranych z okręgu nr 9, w okresie trwania kampanii wyborczej w zestawieniu z okresem po wyborach do Parlamentu Europejskiego oraz odpowiedź na postawione we wstępie pytanie badawcze czy posłowie prowadzą aktywną i systematyczną komunikację z użytkownikami portalu Facebook. Natomiast analiza przypadków posłużyła do przeglądu wszystkich komentarzy, dyskusji, zdjęć, relacji i materiałów zamieszczonych na stronach poszczególnych eurodeputowanych, co umożliwiło zweryfikowanie hipotezy dotyczącej aktywności mającej na celu kreowanie wizerunku.

\section{Facebook i jego znaczenie dla kreowania wizerunku polityka}

Podejmując rozważania dotyczące wykorzystania portalu Facebook przez polityków oraz osoby aspirujące do pełnienia funkcji publicznych, należy zwrócić uwagę na to, iż ogromnym sukcesem serwisów społecznościowych, w tym również omawianego w artykule portalu Facebook, stało się budowanie wirtualnych platform komunikacji i spotkań, tj. zawierania znajomości za pośrednictwem sieci. Innymi słowy, to właśnie m.in. portal Facebook pozwolił czy też ułatwił nawiązywanie relacji międzyludzkich przez swoich użytkowników (Lusińska, 2016, s. 244).

Warto zauważyć, że wśród zalet portalu Facebook można wymienić m.in.:

- utrzymywanie kontaktu z przyjaciółmi i znajomymi (w przypadku polityków z wyborcami), 
- pozyskiwanie informacji - dostęp do informacji w jednym miejscu,

- komentowanie zdjęć oraz innych treści umieszczanych przez pozostałych użytkowników portalu,

- możliwość prezentowania własnej opinii,

- prowadzenie wirtualnego życia towarzyskiego poprzez udostępnianie zdjęć, uczestnictwo w wydarzeniach, korzystanie $\mathrm{z}$ dostępnych aplikacji i gier razem ze znajomymi,

- zastępstwo innych form komunikacji (np. e-mail, SMS, połączenia telefoniczne) wewnętrznym komunikatorem Facebooka,

- możliwość tworzenia oraz uczestnictwa w grupach zainteresowań,

- możliwość reklamowania własnej firmy i/lub marki osobistej (Szymański, Kowalczyk, 2013, s. 159).

O potencjale portalu Facebook mogą świadczyć dane opublikowane w ostatnim kwartale 2018 roku, z których wynika, iż w samym tylko grudniu z platformy Facebook codziennie korzystało 1,52 mld osób, co stanowi wzrost względem ostatniego kwartału 2017 roku o 9\% (Hekman 2019). Interesujące są również dane dotyczące miesięcznej liczby aktywnych użytkowników. Wskazują one bowiem, iż w samym tylko grudniu 2018 roku przynajmniej raz z Facebooka skorzystało 2,32 mld użytkowników (Liczba użytkowników Facebooka...).

Mając na względzie powyższe informacje, należy również zauważyć, że głównymi użytkownikami mediów społecznościowych, w tym m.in. portalu Facebook, są ludzie młodzi, którzy należą do tzw. pokolenia digital natives, czyli osób, które od dziecka korzystają z technologii informatycznych, tj. komputerów, telefonów komórkowych (smartfonów), tabletów itp. (Gawrol, 2017, s. 54). Osoby młode nie są jednak jedynymi użytkownikami tego typu portali. Facebook powstał bowiem w roku 2004, a od 2008 roku funkcjonuje również w Polsce. Stosunkowo długa (jak na tego typu platformy) obecność na rodzimym rynku pozwoliła wykształcić grupę stałych i dojrzałych użytkowników, która w 2019 roku oscylowała w granicach około $16 \mathrm{mln}$ użytkowników, co w przybliżeniu stanowi ponad 1/3 wszystkich mieszkańców naszego państwa (Burtan, 2019).

Rosnąca liczba użytkowników tego typu portali sprawiła, że media społecznościowe, takie jak m.in. Facebook, w coraz większym stopniu oddziałują na życie społeczne. Popularność platformy wpływa również na zachowania 
wyborcze polityków, a także samych wyborców. Wzrost znaczenia Internetu oraz nowych form komunikowania spowodował zwiększenie aktywności online osób związanych ze światem polityki oraz osób aspirujących do objęcia różnego rodzaju funkcji publicznych pochodzących z wyborów bezpośrednich. Jednym ze sposobów ubiegania się o poparcie elektoratu jest aktywna działalność na portalu Facebook. Począwszy od wyborów prezydenckich w 2015 roku, każdej kolejnej elekcji, oprócz kampanii rzeczywistej, towarzyszy dodatkowa kampania w Internecie. Dzięki zastosowaniu nowoczesnych form komunikowania politycy mogą kształtować wizerunek, który z ich punktu widzenia będzie atrakcyjny dla odbiorców - wyborców. To dzięki użytkowaniu Facebooka politycy mogą konkurować o głosy elektoratu, niezależnie od sympatii czy antypatii mediów tzw. „,mainstreamu”2. Media społecznościowe są zatem doskonała platformą dla kreowania wizerunku oraz marki osobistej polityka. Posługując się pojęciem wizerunku należy wskazać, że jest to termin wieloznaczny, który posiada cały szereg definicji. Jednakże na potrzeby niniejszego artykułu można posłużyć się definicją, w myśl której wizerunek to wyobrażenie jakiegoś stanu rzeczy, obraz myślowy, zespół skojarzeń związanych z danym podmiotem. Innymi słowy, w odniesieniu do tematu niniejszego artykułu wizerunek będzie tym, w jaki sposób polityk jest postrzegany przez społeczeństwo i mass media (Czaplińska, 2015, s. 9). Cechą mediów społecznościowych jest to, iż osoba zainteresowana, tj. polityk, w sposób dowolny może kształtować swój wizerunek, formułując przekaz, który bezpośrednio trafia do odbiorcy - elektoratu. Należy jednak zaznaczyć, że przed przystąpieniem do kreowania wizerunku kluczowym jest poznanie oczekiwań oraz potrzeb wyborców, a następnie przyjęcie ich perspektywy. Nie bez znaczenia jest bowiem fakt, iż celem marketingu politycznego jest wykreowanie kandydata, którego wizerunek będzie odpowiadał oczekiwaniom wyborców (Wojciechowska, 2013, s. 228). W samym procesie kreowania wizerunku należy pamiętać, że musi on być spójny oraz rzeczywisty. W odniesieniu do wizerunku polityka, spójność oznaczać będzie sytuację, w której jego aktywność w mediach społecznościowych będzie tożsama z wartościami i poglądami, które reprezentuje. Natomiast istota rzeczywistości polegać będzie na ukazywaniu polityka z jak

\footnotetext{
2 Potoczna nazwa dla mediów głównego nurtu.
} 
najlepszej strony, jednakże bez uciekania się do nieetycznych chwytów marketingowych czy manipulacji. Polityk nawet w mediach społecznościowych musi być wiarygodny oraz wzbudzać zaufanie.

\section{Aktywność eurodeputowanych na Facebooku - analiza porównawcza}

W 2019 roku na obszarze państw członkowskich Unii Europejskiej odbyły się wybory do Parlamentu Europejskiego IX kadencji (w Polsce miało to miejsce w dniu 26 maja). W województwie podkarpackim o głosy wyborców ubiegało się 68 kandydatów startujących z list siedmiu komitetów wyborczych (Wybory do europarlamentu 2019...). Ostatecznie spośród wszystkich osób ubiegających się o mandat eurodeputowanego wybrani zostali: Tomasz Poręba i Bogdan Rzońca z partii Prawo i Sprawiedliwość oraz Elżbieta Łukacijewska z Platformy Obywatelskiej.

Tomasz Poręba z wykształcenia jest historykiem i politologiem. W latach 90. pracował w Kancelarii Prezesa Rady Ministrów, a następnie w Instytucie Pamięci Narodowej w Warszawie. W 2009 roku po raz pierwszy uzyskał mandat eurodeputowanego VII kadencji. Przez objęciem funkcji europosła pracował w Brukseli jako Główny Doradca Grupy Unia na Rzecz Europy Narodów przy Komisji Spraw Zagranicznych Parlamentu Europejskiego. W roku 2014 oraz 2019 ubiegał się o reelekcje i ponownie uzyskał mandat eurodeputowanego (Tomasz Poręba-Poseł do Parlamentu Europejskiego).

Bogdan Rzońca w 2011 roku na Uniwersytecie Jagiellońskim obronił rozprawę doktorską z zakresu zarządzania. Uprzednio był nauczycielem. Pracował w Studium Nauczycielskim w Jaśle, a następnie w Zespole Szkół Ekonomicznych w tej miejscowości. Pod koniec lat 90. był wojewodą krośnieńskim oraz marszałkiem województwa podkarpackiego. W 2011 roku po raz pierwszy został wybrany na posła do Sejmu RP VII kadencji. W roku 2015 ubiegał się o reelekcję i ponowie został wybrany do parlamentu krajowego (Bogdan Józef Rzońca). W 2019 roku z powodzeniem ubiegał się o mandat posła do Parlamentu Europejskiego z ramienia partii Prawo i Sprawiedliwość w okręgu nr 9, zajmując drugie miejsce na liście.

Elżbieta Łukacijewska pochodzi z Podkarpacia. W latach 1998-2001 pełniła funkcję wójta gminy Cisna w Bieszczadach. W roku 2001 po raz pierwszy 
została wybrana na posła do Sejmu RP IV kadencji. Z powodzeniem ubiegała się o reelekcję w 2005 oraz 2007 roku. W roku 2009 po raz pierwszy uzyskała mandat posła do Parlamentu Europejskiego, startując z listy Platformy Obywatelskiej. W 2014 oraz 2019 roku z powodzeniem ubiegała się o reelekcję (Elżbieta Łukacijewska-Poset do Parlamentu Europejskiego).

Celem artykułu jest porównanie aktywności podkarpackich europosłów IX kadencji na portalu społecznościowym Facebook zestawiając ze sobą okres przedwyborczy z okresem powyborczym. Przed przystąpieniem do części badawczej należy zauważyć, że zjawiskiem charakterystycznym dla kampanii wyborczych jest to, iż w tym okresie wielu polityków (szczególnie tych, którzy dopiero zaczynają swoją działalność publiczną) rozpoczyna swoją aktywność w mediach społecznościowych. Nie byłoby w tym nic dziwnego, gdyby nie fakt, iż część profili po zakończeniu kampanii wyborczej „umiera”, tzn. że aktywność na tych kontach jest sporadyczna lub nie ma jej w ogóle, aż do czasu rozpoczęcia kolejnej kampanii. Poddając analizie Facebookowe profile Elżbiety Łukacijewskiej, Tomasza Poręby oraz Bogdana Rzońcy, takie zagrożenie nie występuje, bowiem są to politycy, którzy od lat pełnią swoje funkcje publiczne, a w 2019 roku zostali wybrani na posłów do Parlamentu Europejskiego, zatem ich aktywność w mediach społecznościowych winna być nieprzerwana.

Dokonując analizy aktywności podkarpackich eurodeputowanych IX kadencji, w pierwszej kolejności należy dokonać tabelarycznego zestawienia zawierającego informację o liczbie polubień oraz liczbie odbiorców dla stron poszczególnych europosłów. Informacje na ten temat zostały przedstawione w tabeli 1.

Tabela 1. Oficjalne strony podkarpackich europosłów IX kadencji na portalu Facebook

\begin{tabular}{|l|l|c|c|}
\hline Imię i nazwisko europosła & $\begin{array}{l}\text { Nazwa strony na portalu } \\
\text { Facebook }\end{array}$ & $\begin{array}{c}\text { Liczba } \\
\text { polubień } \\
\text { strony }\end{array}$ & $\begin{array}{c}\text { Liczba osób } \\
\text { obserwują- } \\
\text { cych stronę }\end{array}$ \\
\hline Elżbieta Łukacijewska & Elżbieta Lukacijewska & 8113 & 8113 \\
\hline Tomasz Poręba & $\begin{array}{l}\text { Tomasz Poręba - Poseł do } \\
\text { Parlamentu Europejskiego }\end{array}$ & 6058 & 6060 \\
\hline Bogdan Rzońca & Bogdan Rzońca & 1984 & 2003 \\
\hline
\end{tabular}

Źródło: opracowanie własne na podstawie informacji zawartych na portalu społecznościowym Facebook z dnia 8 lipca 2019 roku. 
Z zaprezentowanych danych wynika, iż wszyscy podkarpaccy eurodeputowani prowadzą swoje oficjalne profile na portalu społecznościowym Facebook i korzystają z tej formy komunikowania. Biorąc pod uwagę wyłącznie liczbę polubień oraz liczbę osób obserwujących stronę możemy zauważyć, że w zestawieniu całej trójki eurodeputowanych to profil Elżbiety Łukacijewskiej dysponuje największym potencjałem. Konto posłanki polubiło i obserwuje bowiem więcej użytkowników Facebooka niż Tomasza Poręby i Bogdana Rzońcy razem. Nie oznacza to jednak, że stronę z góry można uznać za najlepiej prowadzoną. W tym celu potrzeba dokonać analizy aktywności wszystkich deputowanych, zarówno w okresie przedwyborczym, jak również w okresie powyborczym, a następnie dokonać ich zestawienia.

Celem przypomnienia należy wskazać, że badany okres przedwyborczy obejmował ostatnie trzy tygodnie kampanii wyborczej, tj. od dnia 6 maja do 24 maja 2019 roku, natomiast okres powyborczy obejmował trzy tygodnie po ogłoszeniu wyników wyborów, tj. od dnia 27 maja do 14 czerwca 2019 roku. Zarówno w pierwszym, jak i w drugim okresie porównane zostały wszystkie wpisy (posty) zamieszczone na stronach europosłów - zdjęcia, materiały wideo, plakaty, ulotki, relacje itp., a także wszystkie reakcje pozostawione przez pozostałych użytkowników portalu Facebook - komentarze, dyskusje, udostępnienia. Dzięki temu możliwym było zweryfikowanie sformułowanych we wstępie hipotez oraz odpowiedź na postawione pytania badawcze. Informacje dotyczące aktywności w okresie przedwyborczym zostały przedstawione $\mathrm{w}$ tabeli 2 , natomiast informacje dotyczące okresu powyborczego w tabeli 3 . 
Tabela 2. Aktywność przedwyborcza podkarpackich europosłów IX kadencji

\begin{tabular}{|c|c|c|c|c|c|c|}
\hline $\begin{array}{l}\text { Nazwa strony na } \\
\text { portalu Facebook }\end{array}$ & 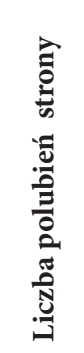 & 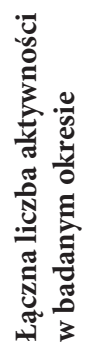 & 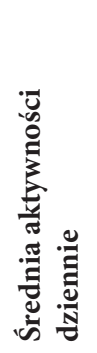 & 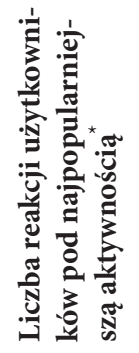 & 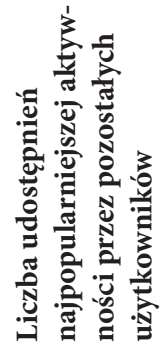 & 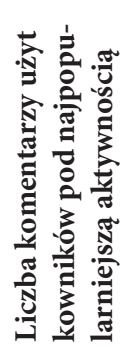 \\
\hline $\begin{array}{l}\text { Elżbieta } \\
\text { Łukacijewska }\end{array}$ & 8113 & 147 & 7.73 & 1.8 tys. & 63 & 416 \\
\hline $\begin{array}{l}\text { Tomasz Poręba - } \\
\text { Poseł do Parlamentu } \\
\text { Europejskiego }\end{array}$ & 6058 & 14 & 0.73 & 184 & 14 & 24 \\
\hline Bogdan Rzońca & 1984 & 9 & 0.47 & 199 & 20 & 68 \\
\hline
\end{tabular}

Źródło: opracowanie własne na podstawie informacji zawartych na portalu społecznościowym Facebook z dnia 8 lipca 2019 roku.

Tabela 3. Aktywność powyborcza podkarpackich europosłów IX kadencji

\begin{tabular}{|c|c|c|c|c|c|c|}
\hline $\begin{array}{l}\text { Nazwa strony na } \\
\text { portalu Facebook }\end{array}$ & 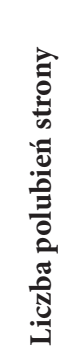 & 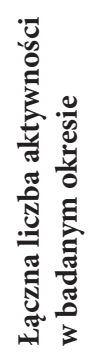 & 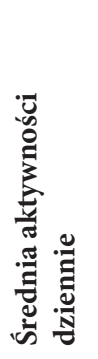 & 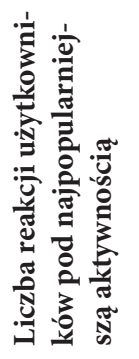 & 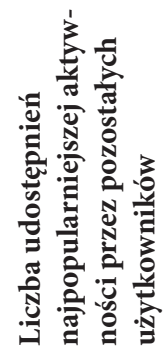 & 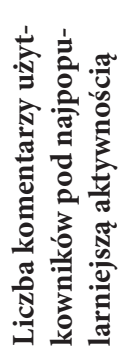 \\
\hline $\begin{array}{l}\text { Elżbieta } \\
\text { Łukacijewska }\end{array}$ & 8113 & 23 & 1.21 & 741 & 13 & 45 \\
\hline $\begin{array}{l}\text { Tomasz Poręba - } \\
\text { Poseł do Parlamentu } \\
\text { Europejskiego }\end{array}$ & 6058 & 4 & 0.21 & 435 & 66 & 76 \\
\hline Bogdan Rzońca & 1984 & 3 & 0.15 & 248 & 7 & 59 \\
\hline
\end{tabular}

Źródło: opracowanie własne na podstawie informacji zawartych na portalu społecznościowym Facebook z dnia 8 lipca 2019 roku.

*Za najpopularniejszą aktywność uważa się wpis, który uzyskał największy wynik sumy reakcji, komentarzy i udostępnień ze strony pozostałych użytkowników portalu Facebook. 
Z zaprezentowanych powyżej danych można wyciągnąć szereg wniosków. Po pierwsze, co naturalne, aktywność przedwyborcza w znacznym stopniu przewyższa aktywność powyborczą. Szczególnie widoczne jest to w przypadku profilu Elżbiety Łukacijewskiej, która w badanym okresie przedwyborczym publikowała blisko osiem wpisów dziennie, co na tle pozostałych deputowanych stanowi bardzo wysoki wynik. Tomasz Poręba oraz Bogdan Rzońca publikowali mniej niż jeden post dziennie. Sporadyczna aktywność jest zaskakująca szczególnie w przypadku europosła Poręby, bowiem jest on jednym $\mathrm{z}$ liderów polskiej delegacji w Brukseli, a w latach ubiegłych należał do prezydium frakcji Europejskich Konserwatystów i Reformatorów. Niska aktywność Bogdana Rzońcy może wynikać z faktu, że jest on politykiem lokalnym, a swoją kampanię wyborczą zbudował na podstawie bezpośrednich kontaktów $\mathrm{z}$ wyborcami oraz rozpoznawalności w regionie. $\mathrm{Z}$ uwagi na zawężone ramy niniejszego artykułu nie sposób odpowiedzieć na pytanie dlaczego europosłowie Prawa i Sprawiedliwości sporadycznie korzystali z komunikacji za pośrednictwem portalu Facebook. Owo zagadnienie wymagałoby pogłębionych badań. Mając na względzie wysoką aktywność Elżbiety Łukacijewskiej oraz sporadyczną aktywność Tomasza Poręby oraz Bogdana Rzońcy, warto przywołać wyniki wyborów do Parlamentu Europejskiego IX kadencji w województwie podkarpackim i sprawdzić, jak w rzeczywistości aktywność na portalu Facebook przełożyła się na ostateczne wyniki wyborów. Informacje dotyczące wyników wyborów zostały przedstawione w tabeli 4 .

Tabela 4. Liczba głosów wyborców uzyskanych przez posłów do Parlamentu Europejskiego IX kadencji

\begin{tabular}{|l|c|}
\hline Imię i nazwisko & Liczba uzyskanych głosów \\
\hline Elżbieta Łukacijewska & 40737 \\
\hline Tomasz Poręba & 276014 \\
\hline Bogdan Rzońca & 64113 \\
\hline
\end{tabular}

Źródło: opracowanie własne na podstawie informacji zawartych na stronie Państwowej Komisji Wyborczej z dnia 9 lipca 2019 roku. 
Mając do dyspozycji dane dotyczące aktywności przedwyborczej, w zestawieniu z oficjalnymi wynikami wyborów do Parlamentu Europejskiego IX kadencji w okręgu nr 9, można zauważyć, że zdecydowanym zwycięzcą został Tomasz Poręba, który uzyskał ponad dwukrotnie więcej głosów niż pozostali europosłowie razem. Drugie miejsce zajął Bogdan Rzońca, a trzecie Elżbieta Łukacijewska. Bardzo wysoki wynik Poręby oraz Rzońcy potwierdzają postawioną we wstępie hipotezę, że wzmożona aktywność na portalu społecznościowym Facebook nie przekłada się na ostateczny sukces wyborczy.

\section{Analiza treści materiałów udostępnionych na Facebooku - uwagi końcowe}

Na koniec warto się odnieść do aktywności powyborczej oraz samych treści zamieszczanych na profilach poszczególnych europosłów. Podobnie jak w przypadku okresu przedwyborczego, najaktywniejsza okazała się Elżbieta Łukacijewska, która w badanym okresie opublikowała 23 wpisy. Średnio daje to ponad jeden post dziennie. Treści, które są zamieszczane na stronie posłanki, to w głównej mierze zdjęcia oraz materiały wideo, w których Łukacijewska informuje o swojej aktywności. Dzięki analizie profilu można wnioskować, że Elżbieta Łukacijewska samodzielnie prowadzi swoją stronę na portalu Facebook, co nie często jest spotykane wśród osób publicznych. Dzięki temu jej wizerunek jest bardziej wiarygodny. Najpopularniejszym postem zamieszczonym na profilu Łukacijewskiej w okresie przedwyborczym było zdjęcie z Donaldem Tuskiem, byłym premierem oraz przewodniczącym Rady Europejskiej.

W okresie powyborczym było to natomiast nowe zdjęcie profilowe posłanki. Aktywność Tomasza Poręby oraz Bogdana Rzońcy, podobnie jak w okresie przedwyborczym, była sporadyczna. Poręba opublikował cztery wpisy w ciągu 19 dni, a Rzońca trzy wpisy. W przypadku Tomasza Poręby najpopularniejszym postem w okresie przedwyborczym był wpis zachęcający do lektury wywiadu na temat 10 lat pracy w Parlamencie Europejskim, który ukazał się w magazynie ViP Biznes i Styl (Gieroń 2019).

W okresie powyborczym był to materiał video z TVP Rzeszów, w którym Tomasz Poręba podziękował za wszystkie głosy poparcia otrzymane ze strony 


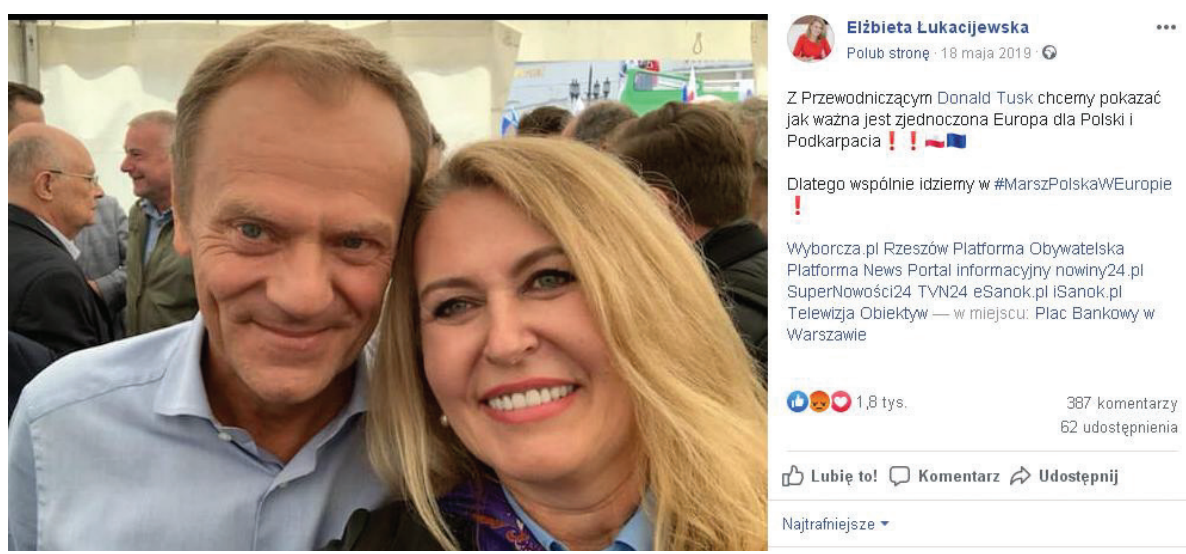

Rys. 1. Najpopularniejszy post Elżbiety Łukacijewskiej w okresie przedwyborczym

Źródło: https://www.facebook.com/lukacijewska/photos/a.1309446729132934/21436 42089046723/?type=3\&theater [dostęp: 7 marca 2020].

Tomasz Poręba -
Poseł do
Parlamentu
Europejskiego
@porebatomasz
strona główna
Informacje
Zdjęcia
Youtube
Filmy
Posty
Społeczność

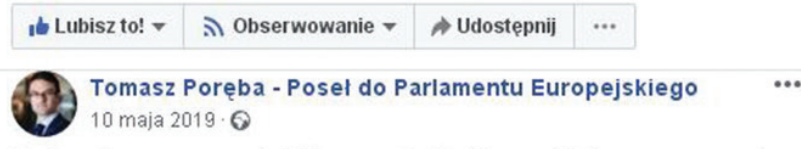

Serdecznie zapraszam do lektury wywiadu jakiego udzieliłem magazynowi VIP Biznes i Styl na temat 10 lat mojej pracy w Parlamencie Europejskim.

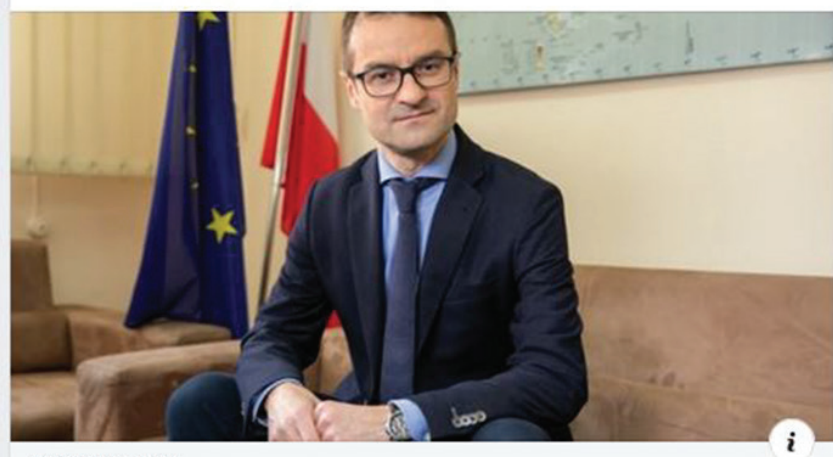

BIZNESISTYL.PL

Z Unii dostaliśmy nie tylko zastrzyk gotówki, ale też entuzjazm i dobre praktyki

\section{9}

凹马 Lubię to!
14 komentarzy 24 udostępnienia

Komentarz

Rys. 2. Najpopularniejszy post Tomasza Poręby w okresie przedwyborczym

Źródło: https://www.facebook.com/porebatomasz/ [dostęp: 7 marca 2020]. 


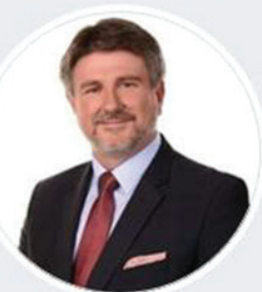

Bogdan Rzońca

(C) PoselBogdanRzonca

Strona glówna

Posty

Filmy

Zdjęcia

Informacje

Społeczność

Wydarzenia

Utwórz strone
It Lubię to!
B) Obserwuj
Adostepni

Bogdan Rzońca

19 maja 2019 .

Rozwój transportu kolejowego na Podkarpaciu jest od wielu lat przedmiotem mojego szczególnego zainteresowania. Dzięki pracy Sejmowej Komisji Infrastruktury, której przewodniczę, udało się pozyskać 2,6 miliarda złotych na rozwój kolei w naszym regionie. Na całym świecie pociagi wróciły do łask - Podkarpacie nie może być gorsze.

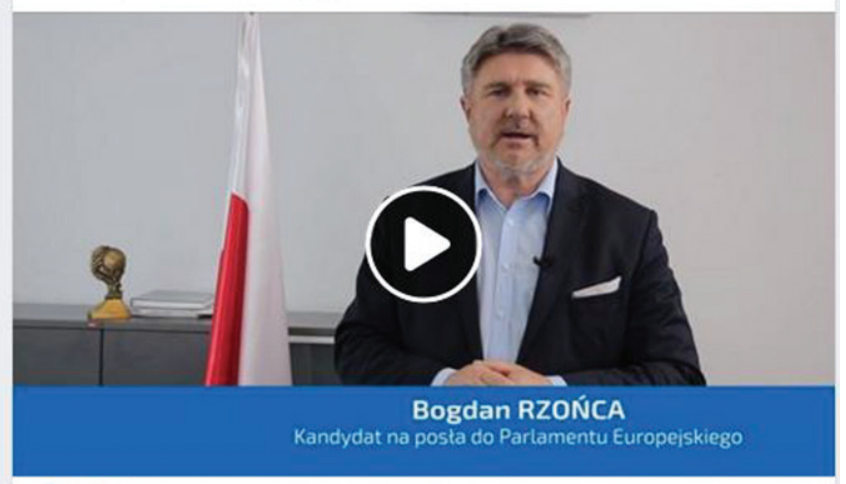

부울 199

65 komentarzy 20 udostępnień

D) Lubię to!

Komentarz

ळ Udostępnij

Rys. 3. Najpopularniejszy post Bogdana Rzońcy w okresie przedwyborczym

Źródło: https://www.facebook.com/PoselBogdanRzonca/ [dostęp: 7 marca 2020].

mieszkańców Podkarpacia. W przypadku Bogdana Rzońcy najpopularniejszym postem przedwyborczym był spot, który zachęcał, aby w wyborach do Parlamentu Europejskiego poprzeć jego kandydaturę.

W okresie powyborczym był to wpis zawierający podziękowania za wszystkie otrzymane głosy poparcia.

\section{Wnioski}

Internet oraz media społecznościowe mają coraz większy wpływ na życie współczesnego człowieka - obywatela. Wśród osób publicznych działalność na takich portalach jak m.in. Facebook jest zjawiskiem powszechnym. Kampania wyborcza prowadzona online stała się stałym elementem każdej 
elekcji. Należy jednak zauważyć, że funkcjonowanie w tzw. „świecie wirtualnym" stanowi dodatek do tradycyjnych form komunikacji na linii politycy - elektorat i jak pokazują przedstawione w artykule badania popularność w Internecie nie przekłada się bezpośrednio na najlepszy wynik w danym okręgu wyborczym.

\section{MGR DOMINIK BORATYN}

Instytut Nauk o Polityce

Uniwersytet Rzeszowski

al. mjr. W. Kopisto 2a, 35-959 Rzeszów

dk.boratyn@gmail.com

\section{Bibliografia}

Adamik-Szysiak, M. (2014a). Social media marketing - kreowanie wizerunku polityka w przestrzeni wirtualnej na przykładzie liderów polskiej sceny politycznej. Rocznik Nauk Społecznych, 1.

Adamik-Szysiak, M. (2014b). Twitter in Communication Strategies of the Leaders of the Polish Political Parties. e-Politicon, 9.

Andersen, K.N., Medaglia R. (2009). The Use of Facebook in National Election Campaigns: Politics as Usual? W: A. Macintosh, E. Tambouris (red.). Electronic participation. Linz: Springer.

[b.a.] (2019). Liczba użytkowników Facebooka zwiększa się mimo skandali, PRoto.pl. Pobrane z: http://www.proto.pl/aktualnosci/liczba-uzytkownikow-facebookazwieksza-sie-mimo-skandali.

[b.a.] (2019). Wybory do europarlamentu 2019. Kandydaci z Podkarpacia - jest 7 komitetów i 68 nazwisk [LISTY WYBORCZE], nowiny24.pl. Pobrane z: https:// nowiny24.pl/wybory-do-europarlamentu-2019-kandydaci-z-podkarpacia -jest-7-komitetow-i-68-nazwisk-listy-wyborcze/ar/c1-14124187.

Bąk, A., Kubisz-Muła, L. (2017). Facebook jako narzędzie odwoływania się do ogólnokrajowych sporów politycznych przez lokalnych polityków - analiza na przykładzie samorządowców z miast na prawach powiatu z województwa śląskiego. Polityka i Społeczeństwo, 4.

Bodys, M. (2015). Wykorzystanie mediów społecznościowych przez polskie parlamentarne partie polityczne poza okresem kampanii wyborczych. Wrocławskie Studia Politologiczne, 18.

Bodys, M. (2016). Rola mediów społecznościowych w komunikacji partii politycznych i podejmowaniu decyzji wyborczych przez ich wyborców. Political Preferences, No. 12 . 
Boratyn, D. (2018). Wizerunek kandydatów na urząd prezydenta miasta Rzeszowa na portalu społecznościowym Facebook a preferencje wyborcze elektoratu. UR Journal of Humanities and Social Sciences, 4(9).

Bossetta, M., Dutceac Segesten, A., Trenz, H.-J. (2017). Engaging with European Politics through Twitter and Facebook: Participation beyond the National? W: M. Barisione, A. Michailidou (red.). Social media and European Politics: Rethinking Power and Legitimacy in the Digital Era. Londyn: Palgrave Macmillan.

Burtan, G. (2019). 15 lat Facebooka. W Polsce przyjąt się znakomicie - i jego wady te $\dot{z}$, WP.pl. Pobrane z: https://tech.wp.pl/15-lat-facebooka-w-polsce-przyjal-sie-znakomicie-i-jego-wady-tez-6345847718799489a.

Choroś, B., Skrabacz, E. (2014a). Komunikacja polityczna w Internecie na szczeblu lokalnym. Rekonesans badawczy. Polityka i Społeczeństwo, 3.

Choroś, B., Skrabacz, E. (2014b). Internetowa aktywność polityków na szczeblu lokalnym - wyborcza i pozawyborcza komunikacja polityczna (przypadek województwa opolskiego).e-Politicon, 16.

Czaplińska, P. (2015). Strategia budowania wizerunku osób znanych. W: A. Grzegorczyk (red.). Perswazyjne wykorzystanie wizerunku osób znanych. Warszawa: Wyższa Szkoła Promocji.

Gawrol, K. (2017). Rola mediów społecznościowych w edukacji - stan obecny i perspektywy rozwoju. Dydaktyka Informatyki, 12.

Gieroń, A. (2019). Z Unii dostaliśmy nie tylko zastrzyk gotówki, ale też entuzjazm i dobre praktyki, BIZNESiSTYL.pl. Pobrane z: https://www.biznesistyl.pl/ludzie/wywiady/8201_nii-dostalismy-nie-tylko-zastrzyk-gotowki,-ale-tez-entuzjazm-i-dobre-praktyki.html?fbclid=IwAR26nM1daI0xmbi7ePfUxAHhCZQvar3GVvEVGzlEBtl_5HYibKRivmVNPw8.

Fung, A., Russon Gilman, H., Shkabatur, J. (2013). Six Models for the Internet + Politics. International Studies Review, 15.

Hekman, P. (2019). Facebook coraz większy. Zysk, liczba użytkowników... i fałszywych kont rosna, wyborcza.pl. Pobrane z: http://wyborcza.pl/7,156282,24415744,facebook-coraz-wiekszy-zysk-liczba-uzytkownikow-i-falszywych.html.

Lusińska, A. (2016). Social media a kampanie społeczne. „Facebook to nie życie” jako przykład kampanii społecznej o i na facebooku. Zarządzanie Mediami, t. 4(4).

Marszałek-Kawa, J., Plecka, D. (red.). (2018). Leksykon wiedzy politologicznej. Toruń: Wydawnictwo Adam Marszałek.

Olszanecka-Marmola, A. (2015). Wykorzystywanie serwisu Facebook w komunikowaniu politycznym na szczeblu lokalnym - przypadek województwa śląskiego. Vademecum Śląsk, 3.

Portal społecznościowy Facebook. Pobrane z: https://www.facebook.com/.

Posyłek, M. (2017a). Rola mediów społecznościowych w komunikowaniu politycznym. Polityka i Społeczeństwo, 1.

Posyłek, M. (2017b). Rola mediów społecznościowych w procesie budowania wizerunku kobiet prezydentów miast na przykładzie serwisu Facebook. Polityka i Społeczeństwo, 4.

Strona Internetowa Bogdan Józef Rzońca. Pobrane z: http://bogdanrzonca.eu/o-mnie. 
Strona Internetowa Elżbieta Łukacijewska - Poseł do Parlamentu Europejskiego. Pobrane z: http://www.lukacijewska.pl/o-mnie.

Strona Internetowa Państwowej Komisji Wyborczej. Pobrane z: https://wybory.gov.pl/ pe2019/pl/wyniki/pl.

Strona Internetowa Tomasz Poręba - Poseł do Parlamentu Europejskiego. Pobrane z: http://www.tomaszporeba.pl/?pg=omnie.

Szwed-Walczak, A. (2017). Komunikowanie ugrupowań politycznych na Facebooku w trakcie kryzysu sejmowego na przełomie 2016 i 2017 roku. Polityka i Społeczeństwo, 4 .

Sveningsson, M. (2014). „I don't like it and I think it's useless, people discussing politics on Facebook": Young Swedes' understandings of social media use for political discussion. Cyberpsychology: Journal of Psychosocial Research on Cyberspace, 8(3).

Szymański, G., Kowalczyk, A. (2013). Facebook realnym zagrożeniem współczesnego społeczeństwa. Zeszyty Naukowe Uniwersytetu Szczecińskiego. Studia Informatica, 33.

Wojciechowska, I. (2013). Spójność wizerunku w polityce. Humanities and Social Sciences, XVIII, 20(3). 